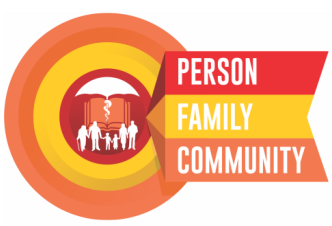

Journal Homepage:

https://jurnal.ugm.ac.id/rpcpe

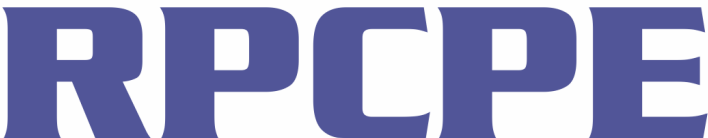

ISSN 2613-943X (print) ISSN 2620-5572 (online)

Review of Primary Care Practice and Education (Kajian Praktik dan Pendidikan Layanan Primer)

\title{
Concept of Primary Care Clinic Facilities and Management in the New Era of Covid-19
}

Trevino Aristarkus Pakasi ${ }^{1}$, Dhanasari Vidawati Trisna ${ }^{1}$, Levina Stephanie Pakasi ${ }^{3}$

\footnotetext{
${ }^{1}$ Department of Community Medicine; Faculty of Medicine; University of Indonesia; Indonesia

${ }^{2}$ Department of Community Medicine; Faculty of Medicine; University of Indonesia; Indonesia

${ }^{3}$ Faculty of Travel Medicine; Royal College of Physicians and Surgeons of Glasgow; United Kingdom
}

Presented at the webinar organized by the collaboration between the Indonesian Family Medicine College, the Indonesian Family Doctors Association, the Indonesian Society of Teachers in Family Medicine, the Review-Journal on Primary Care Practice and Education, and the Center for Policy Management, the Faculty of Medicine, Gadjah Mada University on April 22, 2020.

Coressponding Author:

Trevino A. Pakasi: Divisi Kedokteran Keluarga Departemen IKK FKUI, Jl. Pegangsaan Timur no. 16, Jakarta Pusat 10320

E-mail: pakasitrevino@gmail.com

To cite this article:

Pakasai TA, Trisna DV, Pakasi LS. Concept of Primary Care Clinic Facilities and Management in the New Era of Covid-19. Rev Prim Care Prac and Educ. 2020; 3(3): 11-13.

\section{INTRODUCTON}

The Covid-19 pandemic that started at the beginning of January 2020, spreading gradually from China throughout the world, and is still ongoing to date ${ }^{1,2}$. The pandemic creates anxiety apart from the spreading very rapidly, but also because of its impact on various aspects ${ }^{3}$. There is no other cause that has accelerated the spread, except the course of human migration itself $f^{4,5}$. Many plans to control the spreading including lockdown, was not working well to achieve the goals ${ }^{6,7}$. Less compliance to the regulation because of the tradition of 'pulang kampung', as well as the economic drive. The tradition is strong enough that even a regulation from the government of Jakarta to control the returning people could not prevent they of going back to Jakarta ${ }^{8}$. Again, the moving people would increase probability of Covid-19 transmission, both sides in the destination and back to Jakarta. It is actually a warning for all health facilities to treat all visitors to have any contact to Covid-19. This was the aim of this concept paper, as to review and propose an idea of manging a safe clinic for both patients and staffs.

\section{THE EPIDEMIOLOGY OF COVID-19}

As a member of coronavirus family, the SARS-CoV2 is quite a special infectious diseases, because of the ability to spread an mimicking so many symptoms ranging from mild to very severe illness, but also asymptomatic patients.

The infection may occur in the respiratory tract as well as in the digestive system. There were also cases of positive swab-PCR test, but developed no symptoms. The rest of the disease are classified as mild, moderate, and severe Covid-199. Uptill September 2020, there are more then 200,000 confirmed cases, followed by more then 8000 cases of fataliy ${ }^{10}$. The impact of Covid-19 was huge compared to the prior corona pandemic, SARS and MERS-CoV ${ }^{11}$ in terms of the number of infected people and the mortality ${ }^{12}$. The susceptible population includes medical doctors and health personnel.

It is important to note that there were three modes of transmission now, namely close contact, airborne and contaminated surface. Previously, the WHO only stated the use of personal protective equipment to prevent close contact and contaminated surface. But, now the transmission through aerosol is also important $\mathrm{t}^{13-15}$. The smaller size of aerosol compares to droplet, allows aerosol to fly and spread farther than droplets ${ }^{9,16,17}$.

\section{ROLE OF AIR QUALITY TO TRANSMIT THE VIRUS}

Setti et al from Italia reported the existing of SARSCoV2 RNA particles in air. He did the study in Bergamo, North Italy by collecting air samples. Worthy to note that North Italy was one of the high impact area because of the Covid- $19^{18}$. We have hypothesized the possibility that SARS-CoV-2 virus could be present on particulate matter (PM Similar confirmation form Germany (Ogen, 2020) that found the association of $\mathrm{NO}_{2}$ high mortality of Covid-19. Two studies in Italy confirmed the same findings that air pollution was associated with high fatality rate of Covid-19 $9^{19,20}$. Wu et al in America reported that particles of 2.5 micron (PM 2.5) that increased $1 \mathrm{ug} / \mathrm{m} 3$ air increase the risk of fatality up to $15 \%{ }^{21}$.

As a reflection to the situation in Indonesia, we could not deny that the air pollution in many big cities is very high. The PM 2.5 is used as an indicator of healthy air 
quality because the particles may enter lung directly into the alveoli. Thus, the possibility of a virus in aerosol $(<5$ micron in size) to enter the respiratory system and reaches the alveoli, will be much higher in a polluted environment.

\section{THE ROLE OF INDOOR AIR QUALITY TO AFFECT HEALTH PERSONNEL IN CLINIC AND HOSPITALS}

The outdoor air pollution would affect the indoor air quality. In other way, due to the air pollution, opening window for ventilation is not recommended in the context of preventing Covid-19. Thus, there must be other way to consider the indoor air quality inside the clinic to ensure safety for the patients and the staffs of the clinic.

NEW CONCEPT CLINIC IN NEW-NORMAL ERA The occupational safety and health for a clinic developed from the HIV pandemic and renewed after the Ebola, that was mainly based on the blood-borne diseases ${ }^{22,24}$. The fact that Covid-19 is an airborne transmission, the environmental control is more difficult. A clinic should make innovation to prevent airborne transmission from staffs to the other staffs, staffs to patients, patients to patients and patients to staffs $^{25,26}$.

1. Online service: the online service might be used for registration, triage, medical history taking, and education continue to the follow up. This service is also applied with the national health insurance (Jaminan Kesehatan Nasional), through mobile application.

2. Offline services, i.e. physical examination, laboratory, and other examination could be delivered upon appointment. In that case, there would be shorter time to wait for the service. Results of the laboratory examination could be delivered online to the doctor, and continuing the consultation through chatting or video conference.

3. Medication could be delivered through an online courier service. There are applications to be used for writing legal prescription, followed by digital payment and delivery directly. In the low resources area, at least a doctor could prescribe and send it to a pharmacy using the free public online social media. After the pharmacy receives the prescription, they could prepare the medication. Patient would then go to the pharmacy only to pick up the medication. Thus, it would short the visiting time to the pharmacy and reduce the close contact between visitors in the waiting room.

4. Room arrangement: consider the capacity of the room to ensure physical distancing, zonation of the room to consider high risk and low risk to Covid-19, as well as to establish a designated room for examining patients with respiratory problems.

5. The use of air-barrier

6. The use of ultraviolet is recommended as terminal disinfection, thus must be used after a service had been done $^{27}$.

7. The use of HEPA filter is recommended to improve indoor air quality. To be detailed engineer in US recommended the filter that could reduce particle less than 0.3 mikron $^{28,29}$.
8. Routine disinfection

9. The use of personal protective equipment as recommended by the Indonesian Medical Association, which is completion of the regulation from the Indonesian government ${ }^{30}$. There are three levels and is meant to be used in relation with the clients.

10. Quality assurance program in the form of regulation, implementation, monitoring and evaluation.

\section{CONCLUSION}

The Covid-19 is the biggest pandemic as written in the history of human mind because the magnituede of the prevalence and affected millions of people with the impact on any other aspect in a community. Though the high impact and low fatality, the pattern was not clear enough how it would affect the susceptible population. Therefore, it is important for medical doctors to prevent the transmission using many modalities, through management of practice, using online service, the use of PPE, controlling the indoor air quality.

\section{ACKNOWLEDGEMENT}

The idea was from LSP as written by TAP, who combined the experience in the university clinic and his private practice. The experience in the university's clinic was under the leading and implementation by DV.

For your note, there are a lot of studies in 2020 related with Covid-19. The disease and its pathogenesis are in ongoing studies. This writing is a concept paper and not a systematic review, which its primary concern is to prevent medical doctors from getting the infection.

\section{REFERENCE}

1. Kemenkes RI. Pedoman Pencegahan dan Pengendalian Coronavirus Disease (Covid-19). Germas. 2020;0-115.

2. WHO. Situation Report Covid-19 Day 125. World Heal Organ [Internet]. 2020;2019(March):2633. Available from: https://www.who.int/ emergencies/diseases/novel-coronavirus-2019

3. Rajkumar RP. Covid-19 and mental health: A review of the existing literature. 2020;(January).

4. Lai AL, Millet JK, Daniel S, Freed JH, Whittaker GR. The association between domestic train transportation and novel coronavirus (2019nCoV) outbreak in China from 2019 to 2020: A data-driven correlational report. 2020;(January):19-20.

5. WHO. Updated WHO advice for international traffic in relation to the outbreak of the novel coronavirus 2019-nCoV [Internet]. Available from: https://www.who.int/news-room/articles-detail/updated-whoadvice-for-international-traffic-in-relation-to-the-outbreak-of-thenovel-coronavirus-2019-ncov

6. Kemenkes RI. PMK-No.9-Th-2020_Pedoman-Pembatasan-Sosial-Berskala-Besar-Dalam-Penanganan-Covid-19.pdf. 2020.

7. Kemenhub. Pengendalian Transportasi Selama Masa Mudik Lebaran. Jakarta; 2020

8. Pemda DKI Jakarta. Panduan Izin Keluar-Masuk Jakarta. Panduan Penggunaan Izin Keluar-Masuk Jakarta. 2020.

9. Susilo A, Rumende CM, Pitoyo CW, Santoso WD, Yulianti M, Sinto R, et al. Coronavirus Disease 2019 : Tinjauan Literatur Terkini Coronavirus Disease 2019 : Review of Current Literatures. J Penyakit Dalam Indones. 2020;7(1):45-67.

10. BNPB. Peta Sebaran [Internet]. 2020. Available from: https://covid19. go.id/peta-sebaran

11. Worldometer. Coronavirus Cases [Internet]. [cited 2020 May 26]. Available from: https://www.worldometers.info/coronavirus/?zarsrc $=130$

12. ECDC. Risk assessment guidelines for infectious diseases transmitted on aircraft (RAGIDA) Middle East Respiratory Syndrome Coronavi- 
rus (MERS-CoV) [Internet]. 2020. Available from: https://www.ecdc. europa.eu/sites/default/files/documents/infectious-diseases-transmitted-on-aircrafts-ragida-risk-assessment-guidelines.pdf

13. WHO. Rational use of personal protective equipment for coronavirus disease (Covid-19) and considerations during severe shortages [Internet]. 2020. [cited 2020 May 26]. Available from: https:// www.who.int/publications-detail/rational-use-of-personal-protective-equipment-for-coronavirus-disease-(Covid-19)-and-considerations-during-severe-shortages

14. WHO. Modes of transmission of virus causing Covid-19: implications for IPC precaution [Internet]. 2020 [cited 2020 May 26]. Available from: https://www.who.int/news-room/commentaries/ detail/modes-of-transmission-of-virus-causing-Covid-19-implications-for-ipc-precaution-recommendations

15. Morawska L, Cao J. Airborne transmission of SARS-CoV-2: The world should face the reality. Environ Int [Internet]. 2020;139(April):105730. Available from: https://doi.org/10.1016/j. envint.2020.105730

16. Tellier R, Li Y, Cowling BJ, Tang JW. Recognition of aerosol transmission of infectious agents: A commentary. BMC Infect Dis. 2019;19(1):1-9.

17. Pan M, Lednicky JA, Wu CY. Collection, particle sizing and detection of airborne viruses. J Appl Microbiol. 2019;127(6):1596-611.

18. Setti L, Passarini F, Gennaro G De, Baribieri P, Perrone MG, Borelli M, et al. SARS-Cov-2 RNA Found on Particulate Matter of Bergamo in Northern Italy: First Preliminary Evidence. medRxiv [Internet]. 2020;2020.04.15.20065995. Available from: https://www.medrxiv. org/content $/ 10.1101 / 2020.04 .15 .20065995 \mathrm{v} 1$ \% 253 fcollection=

19. Martelletti L, Martelletti P. Air Pollution and the Novel Covid-19 Disease: a Putative Disease Risk Factor. SN Compr Clin Med. 2020;10.

20. Sanità di Toppi L, Sanità di Toppi L, Bellini E. Novel Coronavirus: How Atmospheric Particulate Affects Our Environment and Health. Challenges [Internet]. 2020;11(1 PG-6-6):6. Available from: https:// www.mdpi.com/2078-1547/11/1/6 NS -

21. Wu X, Nethery RC, Sabath MB, Braun D, Dominici F. Exposure to air pollution and Covid-19 mortality in the United States: A nationwide cross-sectional study. medRxiv [Internet]. 2020;53(9):1689-99.
Available from: https://www.medrxiv.org/content/10.1101/2020.04.0 $5.20054502 \mathrm{v} 2$

22. BNPB. Panduan Lintas Sektor [Internet]. Jakarta; 2020. Available from: https://covid19.go.id/storage/app/media/Protokol/FINAL Covid-19 Indonesia Cross Sectoral Guidance - 20 May.pdf

23. BNPB. Jika harus tetap bekerja.pdf. 2020.

24. Widyaningrum N (BPOM R, Rosmalasari E (BPOM R, Awalia S (BPOM R, Sasmoyo R (BPOM R, Wardoyo T (BPOM R. Serba Covid Cegah Covid19 Sehat Untuk Semua. Widyaningrum N (BPOM R, Rosmalasari E (BPOM R, editors. Jakarta; 2020.

25. Kemenkes RI. KESELAMATAN PASIEN DENGAN. Вестник Росздравнадзора Jakarta; 2017 p. 5-9.

26. KemenKes RI 2020. PENYELENGGARAAN PELAYANAN KESEHATAN MELALUI PEMANFAATAN TEKNOLOGI INFORMASI DAN KOMUNIKASI DALAM RANGKA PENCEGAHAN PENYEBARAN CORONA VIRUS DISEASE 2019 (Covid-19) Corona. Peraturan Menteri Kesehatan Republik Indonesia Jakarta; 2020 p. 2-6.

27. KemenKes RI. PANDUAN PENCEGAHAN DAN PENGENDALIAN CORONA VIRUS DISEASE 2019 (Covid-19) DI TEMPAT KERJA PERKANTORAN DAN INDUSTRI DALAM MENDUKUNG KEBERLANGSUNGAN USAHA PADA SITUASI PANDEMI. Jakarta; 2020.

28. Miller SL. How to use ventilation and air filtration to prevent the spread of coronavirus indoors [Internet]. Available from: https://theconversation.com/how-to-use-ventilation-and-air-filtration-to-prevent-the-spread-of-coronavirus-indoors-143732

29. EPA U. Air Cleaners, HVAC Filters, and Coronavirus (Covid-19) [Internet]. 2020 [cited 2020 Sep 12]. Available from: https://www.epa. gov/coronavirus/air-cleaners-hvac-filters-and-coronavirus-Covid-19

30. Ginanjar E, Puspitasari A, Rinawati W, Hasibuan RK, Sofiana NA, Satria AB, et al. Standar perlindungan dokter di era Covid-19. Putri VH, editor. Jakarta: Balai Penerbit IDI; 2020. 92 p. 